\title{
Decision Support System for Selection of Assembly Using Profile Matching Method and Simple Additive Weighting Method (Case Study: GKIN Diaspora Church)
} Amesanggeng Pataropura ${ }^{1)}$, Riki ${ }^{2 *)}$, Joshua Geraldo Manu ${ }^{3)}$

${ }^{123}$ Buddhi Dharma University

Jalan Imam Bonjol No. 41, Tangerang, Indonesia

riki@ubd.ac.id

\begin{tabular}{|c|c|}
\hline Article history: & Abstract \\
\hline $\begin{array}{l}\text { Received } 15 \text { October } 2019 ; \\
\text { Revised } 20 \text { October } 2019 ; \\
\text { Accepted } 25 \text { October } 2019 ; \\
\text { Available online } 30 \text { October } 2019\end{array}$ & $\begin{array}{l}\text { The church is a place of worship for Christians who are worshipers, in the church } \\
\text { there are many organizers called the assemblies whose task is to regulate and } \\
\text { manage all kinds of operational activities related to the worship held on Sundays, }\end{array}$ \\
\hline $\begin{array}{l}\text { Keywords: } \\
\text { DSS } \\
\text { Profile Matching } \\
\text { SAW } \\
\text { Church } \\
\text { Selection }\end{array}$ & $\begin{array}{l}\text { administrator or assembly can be chosen by the congregation by conducting a } \\
\text { selection process from the assemblies in the church and to be appointed by the } \\
\text { pastor. The process of selecting the assembly can be an error to choose the assembly } \\
\text { that can be subjective. Then a system for decision-making decision support is made } \\
\text { using the Profile Matching Method and Simple Additive Weighting (SAW) } \\
\text { Method. Where Profile matching is a decision support method using calculation of } \\
\text { weight and weighting by dividing the main factors and supporting factors. And } \\
\text { using the Simple Additive Weighting (SAW) method is a weighted housing } \\
\text { method, by normalizing the decision decision matrix (x) to a scale that can be } \\
\text { compared with all available alternative ratings. }\end{array}$ \\
\hline
\end{tabular}

\section{INTRODUCTION}

Effective leadership is important for all organizations, namely leadership that can move the members of the group in achieving the goals set by the organization. [1]

Meaning of service in the context of the church can be interpreted as serving or serving God and not others [2]. In service, one's lifestyle is no longer living for oneself but living for God and for others. In the context of the church, service can be interpreted as a calling and assignment from God.

The duties and authority of an assembly in the church is the responsibility given by a pastor to administer and regulate the organization of the church. An assembly is chosen to be a good guide for the congregation. And as a servant in taking care of all matters relating to the church, it must be carried out with sincere sincerity, not just to get a job and position in the church.

As an assembly is required to be able to understand and understand that a good assembly is able to lead the congregation to do fellowship, church building and carry out testimony and service in the church.

The selection of assemblies is done based on the elected assembly, chosen by means of kinship with the candidate for assembly chosen by the congregation. With the following criteria: understanding of the Bible, adequate age, understanding the organization, called to serve, and become a role model for the congregation. If the prospective assembly has fulfilled the following requirements, it will undergo guidance with the pastor in accordance with the position (secretary, treasurer, deaconia, and other administrators) to be in accordance with the teachings listed in the Bible.

Then after being able to fulfill all these processes, the prospective assembly will be spent as a church assembly and can undergo work in accordance with their position.

Commitment to service as a determination to serve God, with all your heart, mind, strength, for the sake of his love of service. It can be concluded that service commitment contains a promise, loyalty, that what is decided is a determination or unanimity of someone in doing service [3].

The chosen method is to use the Simple Additive Weighting (SAW) method chosen because the method for calculating the weighted sum, Simple Additive Weighting (SAW) itself must go through the normalization stage to be compared to all available alternative ratings. This method requires the decision maker to determine the weight for 
each attribute. The total score for the alternative is obtained by adding up all the multiplication results between the rating (which can be compared across attributes) and the weight of each attribute.

While Profile Matching is due to determine the criteria and weights in the existing assessment, ie comparing individual competencies into position competencies so that competency differences can be known (also called gaps), the smaller the gap produced, the greater the value weights means having a greater chance of candidates who will occupy these positions.

\section{RELATED WORKS/LITERATURE REVIEW}

\section{Decision Support System}

Decision support system "Defines a decision support system as a computer-based system consisting of three interacting components, a language system (a mechanism to provide communication between users and other decision support system components), a knowledge system (repository of problem domain knowledge that exists in a support system decision or as data or as a procedure), and problem processing systems (the relationship between two other components, consisting of one or more general problem manipulation capabilities needed for decision making) ". [4, p. 1]

\section{Simple Additive Weighting}

According to [5, p. 70], the Simple Additive Weighting Method (SAW) is often also known as the weighted housing method. The basic concept of the SAW method is to find a weighted sum of the performance ratings for each alternative on all attributes. The SAW method requires the decision matrix normalization process (X) to a scale that can be compared with all available alternative ratings. The formula for normalizing it is as follows:

$$
r_{i j}=\left\{\begin{array}{l}
\frac{x_{i j}}{\operatorname{Max} x_{i j}} \\
\frac{\operatorname{Min} x_{y}}{x_{y}}
\end{array}\right.
$$

If $\mathrm{j}$ is the benefit attribute

If $\mathrm{j}$ is the cost

With rij is a normalized performance rating of alternative $\mathrm{Ai}$ on the $\mathrm{Cj}$ attribute; $1=1,2, \ldots ., \mathrm{m}$ and $\mathrm{j}=1,2, \ldots ., \mathrm{n}$.

Information:

1. Max $\mathrm{Xij}=$ The biggest value of each criterion $\mathrm{i}$.

2. $\mathrm{Min} \mathrm{Xij}=$ The smallest value of each criterion $\mathrm{i}$.

3. $\mathrm{Xij}=$ The attribute value owned by each criterion.

4. $\quad$ Benefit $=$ If the biggest value is the best.

5. Cost $=$ If the smallest value is the best.

The preference value for each alternative (Vi) is given as follows:

$$
V i=\sum_{j=1}^{n} w_{j} r_{i j}
$$

A greater Vi value indicates that the Ai alternative is preferred.

Information:

1. $\mathrm{Vi}=$ Ranking for each alternative.

2. $\mathrm{Wj}=$ Ranking weight values (from each criterion).

3. $r i j=$ Normalized performance rating value.

\section{Profile Matching}

The concept of the Profile Matching method is to compare individual competencies into position competencies so that differences in competencies (also known as gaps) can be identified, the smaller the gap produced, the greater the value weights means to have a greater chance of someone occupying the position. [6, p. 88]. The steps of the profile matching method are:

1. Determine variable data needed. 
2. Determine the aspects used for assessment.

3. Gap profile mapping:

$$
\text { Gap = Minimal Profile - Test data profile }
$$

4. After the Gap value is obtained, then weights are given for each Gap value.

5. Calculation and grouping of Core Factors and Secondary Factors. After determining the weight of the gap value, then grouped into 2 groups, namely:

a. Core Factor, which is the most important or prominent criteria (competencies) or most needed by an assessment that is expected to obtain optimal results.

$$
N F C=\frac{E N C}{E I C}
$$

Information:

NFC : The average value of the core factor

NC : The total number of core factor values

IC : Number of core factor items

b. Secondary Factor (supporting factors), which are items other than those in the core factor. Or in other words is a supporting factor that is less needed by an assessment.

$$
N F C=\frac{E N C}{E I S}
$$

Information:

NFS : The average value of the secondary factor

NS : The total number of secondary factor values

IS : Number of secondary factor items

6. Calculation of Total Value. Total value is obtained from the percentage of core factors and secondary factors which are estimated to influence the results of each profile.

$N=(x) \% N C F+(x) \% N S F$

Information:

$\mathrm{N}$ : Total value of the criteria

NFS : The average value of the secondary factor

NFC : The average value of the core factor

(x)\%: The percent value inputted

7. Calculation of ranking. The final result of the profile matching process is ranking. Determination of ranking refers to the results of certain calculations

Ranking $=(x) \% N M A+(x) \% N S A$

Information:

NMA: Total value of the main Aspect criteria

NSA: Total value of Supporting Aspect criteria

(x)\%: The percent value inputted

\section{METHODS}

\section{Problem Analysis}

On the existing problems in the running process of the assembly election system in the Church of the Diaspora GKIN, the problems described are as follows:

1. The assembly is chosen manually (by family) by the congregation and a pastor.

2. Assembly election calculation system is still done manually so that it can trigger elections that are subjective

3. There is no computerized data storage in implementing decision support systems.

After the discovery of the problem analysis, a SWOT analysis is made, namely: 
Table 1. SWOT

\section{Strenght (S) Weakness (W)}

GKIN Diaspora Church has a sufficient number of Does not have a computerized system in assembly congregations and facilities. elections.

Opportunities (O) Threats (T)

GKIN Diaspora Church is located in a location that There are many other churches around the GKIN can be reached by many people Diaspora area

\section{Determine the criteria}

By determining the criteria, a benchmark can be made for someone who makes a decision. The criteria that can become a benchmark in the selection of assemblies are as follows:

Tabel 3. 2 Criteria and Weight

\begin{tabular}{|l|l|l|l|} 
Code & \multicolumn{1}{c|}{$\begin{array}{c}\text { Criteria }\left(\mathrm{C}_{\mathrm{i}}\right) \\
\left(\mathbf{W}_{\mathrm{i}}\right)\end{array}$} & \multicolumn{1}{c}{ A tribut } \\
\hline C1 & Bible understanding & 4 & $\mathrm{~B}$ \\
\hline C2 & Sufficient age & 3 & $\mathrm{~B}$ \\
\hline C3 & Be a role model for the congregation & 5 & B \\
\hline C4 & Marital status & 2 & B \\
\hline C5 & A period of service in the Church & 4 & B \\
\hline
\end{tabular}

The following is the elaboration of the variable values in the criteria obtained in the selection of assemblies in the church, as follows:

1. Understanding the Bible, seen in spirituality by understanding the word of God well in each assembly with the following assessment: very good with a weight of 5 , good with a weight of 4 , enough with a weight of 3 , less good with a weight of 2 , and very bad with a weight 1

2. Sufficient age, i.e., seen from the age of the candidates for the assembly, needed to look for candidates for the assembly seen from the experience they have, so the assessment is as follows:> 40 years with a weight of 5, 3539 years with a weight of 4, 34-30 years with a weight of 3, 29 - 25 years with a weight of 2, and 24 - 20 years with a weight of 1 .

3. Being a role model for the church, seen in its service to each church with the following assessment: yes with a weight of 2 , and no with a weight of 1 .

4. Marital Status, seen from the experience he has in managing his organization, with the following assessment: Yes with a weight of 2 , and No with a weight of 1 .

5. The service period in the church, seen from each year serving and activeness in church activities, with the following assessment: 5 years with a weight of 5, 4 years with a weight of 4, 3 years with a weight of 3,2 years with a weight of 2 , and 1 year with a weight of 1 .

\section{Determine Alternatives}

The following is an alternative in the GKIN Diaspora church.

Table 3. Alternative

\begin{tabular}{|l|l|}
\multicolumn{3}{|c|}{ Alternative } \\
\hline No & \multicolumn{1}{|c|}{ Name } \\
\hline A1 & Mr. Rudol \\
\hline A2 & Mr. Hendrik \\
\hline A3 & Mr. Simon \\
\hline A4 & Mr. Ephi \\
\hline A5 & Mrs. Yuni \\
\hline
\end{tabular}

The following are the ratings that have been obtained from decision makers 
Table 4. Assessment data

\begin{tabular}{|l|l|c|c|c|c|c|}
\hline Code & \multicolumn{1}{|c|}{ Name } & $\begin{array}{c}\text { Bible } \\
\text { understanding }\end{array}$ & $\begin{array}{c}\text { Sufficient } \\
\text { age }\end{array}$ & $\begin{array}{c}\text { Become a } \\
\text { rolemodel }\end{array}$ & $\begin{array}{c}\text { Marital } \\
\text { status }\end{array}$ & $\begin{array}{c}\text { Service } \\
\text { Period }\end{array}$ \\
\hline A1 & Mr. Rudol & 4 & 3 & 2 & 2 & 4 \\
\hline A2 & Mr. Hendrik & 3 & 4 & 2 & 2 & 5 \\
\hline A3 & Mr. Simon & 3 & 4 & 2 & 2 & 3 \\
\hline A4 & Mr. Ephi & 2 & 4 & 2 & 2 & 5 \\
\hline A5 & Mrs. Yuni & 4 & 3 & 2 & 2 & 3 \\
\hline
\end{tabular}

\section{SAW Method}

The formula for normalizing it is as follows:

$$
r_{i j}=\left\{\begin{array}{l}
\frac{x_{i j}}{\operatorname{Max} x_{i j}} \\
\frac{\operatorname{Min} x_{y}}{x_{y}}
\end{array}\right.
$$

Table 5. Normalization

\begin{tabular}{|c|c|c|c|c|c|c|}
\hline Code & Name & $\begin{array}{l}\text { Bible } \\
\text { understanding (+) }\end{array}$ & $\begin{array}{l}\text { Sufficient } \\
\text { age (+) }\end{array}$ & $\begin{array}{l}\text { Become a } \\
\text { rolemodel }(+)\end{array}$ & Marital status (+) & $\begin{array}{l}\text { Service } \\
\text { Period (+) }\end{array}$ \\
\hline A1 & Mr. Rudol & 1 & 0.75 & 1 & 1 & 0.8 \\
\hline A2 & $\begin{array}{l}\text { Mr. } \\
\text { Hendrik }\end{array}$ & 0.75 & 1 & 1 & 1 & 1 \\
\hline A3 & Mr. Simon & 0.75 & 1 & 1 & 1 & 0.6 \\
\hline A4 & Mr. Ephi & 0.5 & 1 & 1 & 1 & 1 \\
\hline A5 & Mrs. Yuni & 1 & 0.75 & 1 & 1 & 1 \\
\hline
\end{tabular}

The preference value for each alternative (Vi) is given as follows:

$$
V i=\sum_{j=1}^{n} w_{j} r_{i j}
$$

Table 6. Ranking

\begin{tabular}{|l|r|r|}
\hline No & Score Pref & Ranking \\
\hline 1 & 0.913889 & 3 \\
\hline 2 & 0.944444 & 2 \\
\hline 3 & 0.855556 & 5 \\
\hline 4 & 0.888889 & 4 \\
\hline 5 & 0.958333 & 1 \\
\hline
\end{tabular}

\section{Profile Matching}

\begin{tabular}{|c|c|c|c|c|}
\hline \multirow{2}{*}{\multicolumn{2}{|c|}{ Alternative }} & \multicolumn{3}{|c|}{ Spiritual Aspects (50\%) } \\
\hline & & C1 (Core Factor) & C3 (Core Factor) & $\begin{array}{l}\text { C5 (Secondary } \\
\text { Factor) }\end{array}$ \\
\hline Code & Name & $\begin{array}{l}\text { Bible } \\
\text { understanding }\end{array}$ & Become a rolemodel & Service Period \\
\hline A1 & Mr. Rudol & 4 & 2 & 4 \\
\hline A2 & Mr. Hendrik & 3 & 2 & 5 \\
\hline A3 & Mr. Simon & 3 & 2 & 3 \\
\hline
\end{tabular}

Table 7. Spiritual Aspects 


\begin{tabular}{|l|l|l|l|l|}
\hline A4 & Mr. Ephi & 2 & 2 & 5 \\
\hline A5 & Mrs. Yuni & 4 & 2 & 3 \\
\hline & Profile Ideal & 4 & 5 & 4 \\
\hline
\end{tabular}

Table 8. Physical aspects

\begin{tabular}{|l|l|c|c|}
\multicolumn{2}{|c|}{ Alternative } & \multicolumn{2}{c|}{ Physical aspects (50\%) } \\
\hline Code & Name & Sufficient age & Marital status \\
\hline A1 & Mr. Rudol & 3 & 2 \\
\hline A2 & Mr. Hendrik & 4 & 2 \\
\hline A3 & Mr. Simon & 4 & 2 \\
\hline A4 & Mr. Ephi & 4 & 2 \\
\hline A5 & Mrs. Yuni & 3 & 2 \\
\hline & Profile Ideal & 3 & 2 \\
\hline
\end{tabular}

1. Core Factor, which is the most important or prominent criteria (competencies) or most needed by an assessment that is expected to obtain optimal results.

$$
N F C=\frac{E N C}{E I C}
$$

Information:

NFC : The average value of the core factor

NC : The total number of core factor values

IC : Number of core factor items

2. Secondary Factor (supporting factors), which are items other than those in the core factor, or in other words is a supporting factor that is less needed by an assessment.

$$
N F C=\frac{E N C}{E I S}
$$

Information:

NFS : The average value of the secondary factor

NS : The total number of secondary factor values

IS : Number of secondary factor items

Table 9. Calculation of Gap and Spiritual aspect weights

\begin{tabular}{|l|l|r|r|r|r|r|r|r|}
\hline Score & \multicolumn{1}{|c|}{ Name } & Gap & Weight & \multicolumn{1}{|c|}{ Gap } & Weight & Gap & Weight \\
\hline A1 & Mr. Rudol & 0 & 5 & -3 & 2 & 0 & 5 \\
\hline A2 & Mr. Hendrik & -1 & 4 & -3 & 2 & 1 & 4.5 \\
\hline A3 & Mr. Simon & -1 & 4 & -3 & 2 & -1 & 4 \\
\hline A4 & Mr. Ephi & -2 & 3 & -3 & 2 & 1 & 4.5 \\
\hline A5 & Mrs. Yuni & 0 & 5 & -3 & 2 & -1 & 4 \\
\hline
\end{tabular}

Table 10. Calculation of Gab and Weight of Physical Aspects

\begin{tabular}{|l|l|r|r|r|r|}
\hline Score & \multicolumn{1}{c}{ Name } & Gap & Weight & Gap & Weight \\
\hline A1 & Mr. Rudol & 0 & 5 & 0 & 5 \\
\hline A2 & Mr. Hendrik & 1 & 4.5 & 0 & 5 \\
\hline
\end{tabular}




\begin{tabular}{|l|l|r|r|r|r|}
\hline A3 & Mr. Simon & 1 & 4.5 & 0 & 5 \\
\hline A4 & Mr. Ephi & 1 & 4.5 & 0 & 5 \\
\hline A5 & Mrs. Yuni & 0 & 5 & 0 & 5 \\
\hline
\end{tabular}

a. Calculation of Total Value. Total value is obtained from the percentage of core factors and secondary factors which are estimated to influence the results of each profile.

$N=(x) \% N C F+(x) \% N S F$

Information:

$\mathrm{N}$ : Total value of the criteria

NFS : The average value of the secondary factor

NFC: The average value of the core factor

(x)\%: The percent value inputted

Table 11. The total value of the Spiritual Aspect Criteria

\begin{tabular}{|l|l|r|r|r|}
\hline Code & \multicolumn{1}{|c|}{ Name } & Core Factor $(\mathbf{6 0 \%})$ & $\begin{array}{c}\text { Secondary } \\
\text { Factor }(\mathbf{4 0} \%)\end{array}$ & $\begin{array}{c}\text { Score } \\
\text { NAR }\end{array}$ \\
\hline A1 & Mr. Rudol & 3.5 & 5 & 4.1 \\
\hline A2 & Mr. Hendrik & 3 & 4.5 & 3.6 \\
\hline A3 & Mr. Simon & 3 & 4 & 3.4 \\
\hline A4 & Mr. Ephi & 2.5 & 4.5 & 3.3 \\
\hline A5 & Mrs. Yuni & 3.5 & 4 & 3.7 \\
\hline
\end{tabular}

Table 12. Total Value of Physical Criteria

\begin{tabular}{|l|l|r|r|r|}
\hline \multicolumn{1}{|c|}{ Code } & \multicolumn{1}{|c|}{$\begin{array}{c}\text { Core Factor } \\
(\mathbf{6 0 \%})\end{array}$} & $\begin{array}{c}\text { Secondary } \\
\text { Factor }(\mathbf{4 0 \% )})\end{array}$ & Score NAJ \\
\hline A1 & Mr. Rudol & 5 & 5 & 4.7 \\
\hline A2 & Mr. Hendrik & 4.5 & 5 & 4.7 \\
\hline A3 & Mr. Simon & 4.5 & 5 & 4.7 \\
\hline A4 & Mr. Ephi & 4.5 & 5 & 5 \\
\hline A5 & Mrs. Yuni & 5 & 5 & 5 \\
\hline
\end{tabular}

b. Calculation of ranking. The final result of the profile matching process is ranking. Determination of ranking refers to the results of certain calculations.

Ranking $=(x) \% N M A+(x) \% N S A$

Information:

NMA: Total value of the main Aspect criteria

NSA: Total value of Supporting Aspect criteria

(x)\%: The percent value inputted.

Table 13. Total Rating Value

\begin{tabular}{|l|l|r|r|r|r|}
\hline \multirow{2}{*}{ Code } & \multicolumn{1}{|c}{ Name } & \multicolumn{1}{c|}{ NAR } & NAJ & \multicolumn{1}{c|}{$\begin{array}{c}\text { Final } \\
\text { score }\end{array}$} \\
\hline A1 & Mr. Rudol & 4.1 & 5 & 4.55 & 1 \\
\hline A2 & Mr. Hendrik & 3.6 & 4.7 & 4.15 & 3 \\
\hline A3 & Mr. Simon & 3.4 & 4.7 & 4.05 & 4 \\
\hline A4 & Mr. Ephi & 3.3 & 4.7 & 4 & 5 \\
\hline A5 & Mrs. Yuni & 3.7 & 5 & 4.35 & 2 \\
\hline
\end{tabular}




\section{RESULTS}

At this stage it is an activity to run a new system process that wants to be created, or wants to update an existing system. And aims to be able to improve the effectiveness of work with the existence of the system. By using two methods, the Simple Additive Weighting (SAW) method and the Profile Matching Method in decision making. The proposed new system is to create an application program that can support computerized based decisions that can support and speed up the process of calculation and assessment to get good results. And also this program is expected to be able to facilitate the pastor or pastor to be able to determine the candidates for the assembly to be elected as administrators in the church.

The following is a description of the proposed system procedure:

\section{Assessment Process}

1. Prospective assemblies who have registered with the assembly will submit their personal data and medical documents to be processed.

2. The Assembly hands over the baptismal letter to the pastor

3. The Assembly uses a decision support system program

4. The Tribunal has obtained the ranking of candidates for the Assembly

5. The Assembly hands over the pastor to be elected.

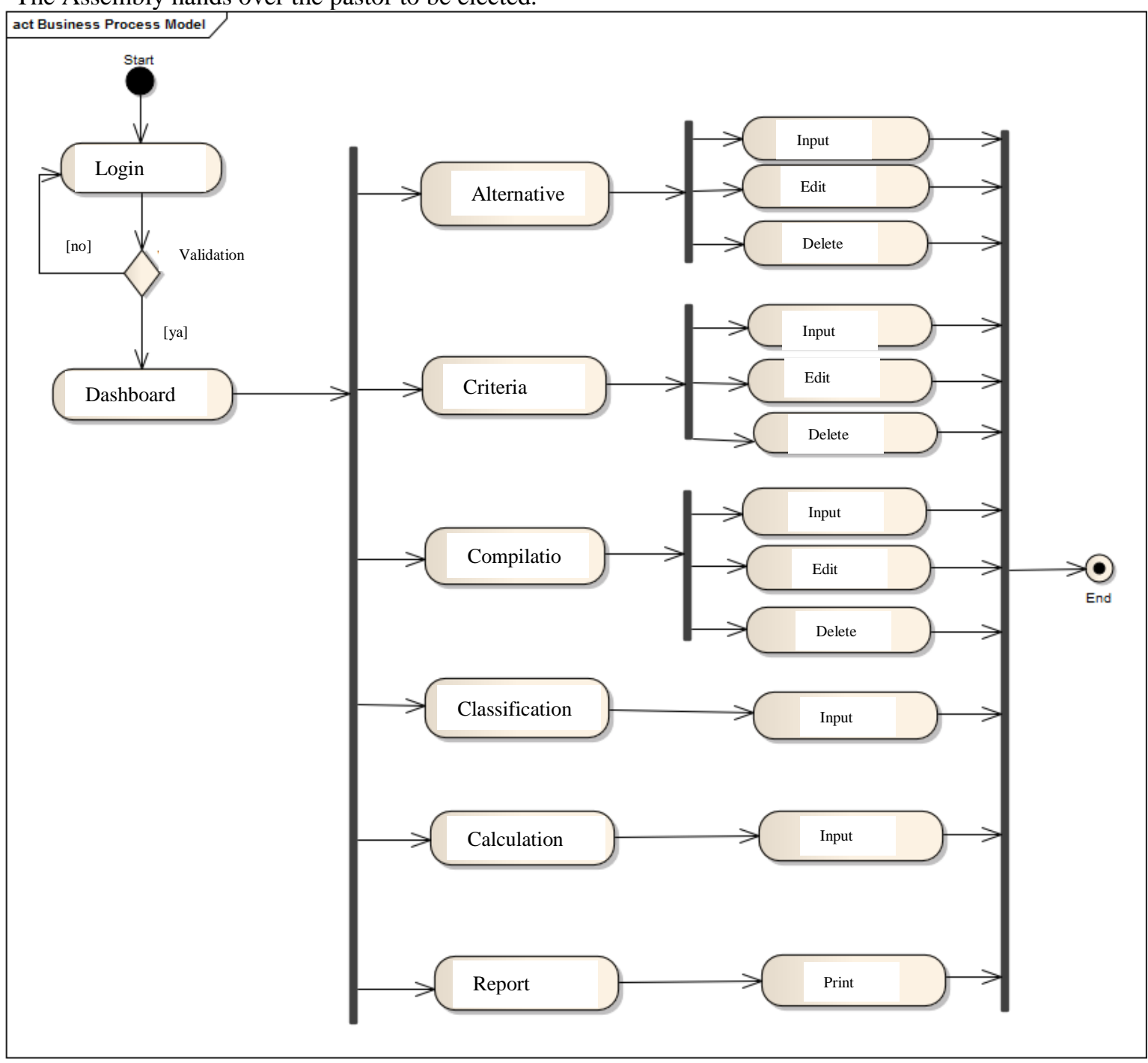

Fig 1. Activity Diagram 
The following figure is the result of the SAW calculation that is made automatically from the calculation of the criteria that have been included in the criteria process.

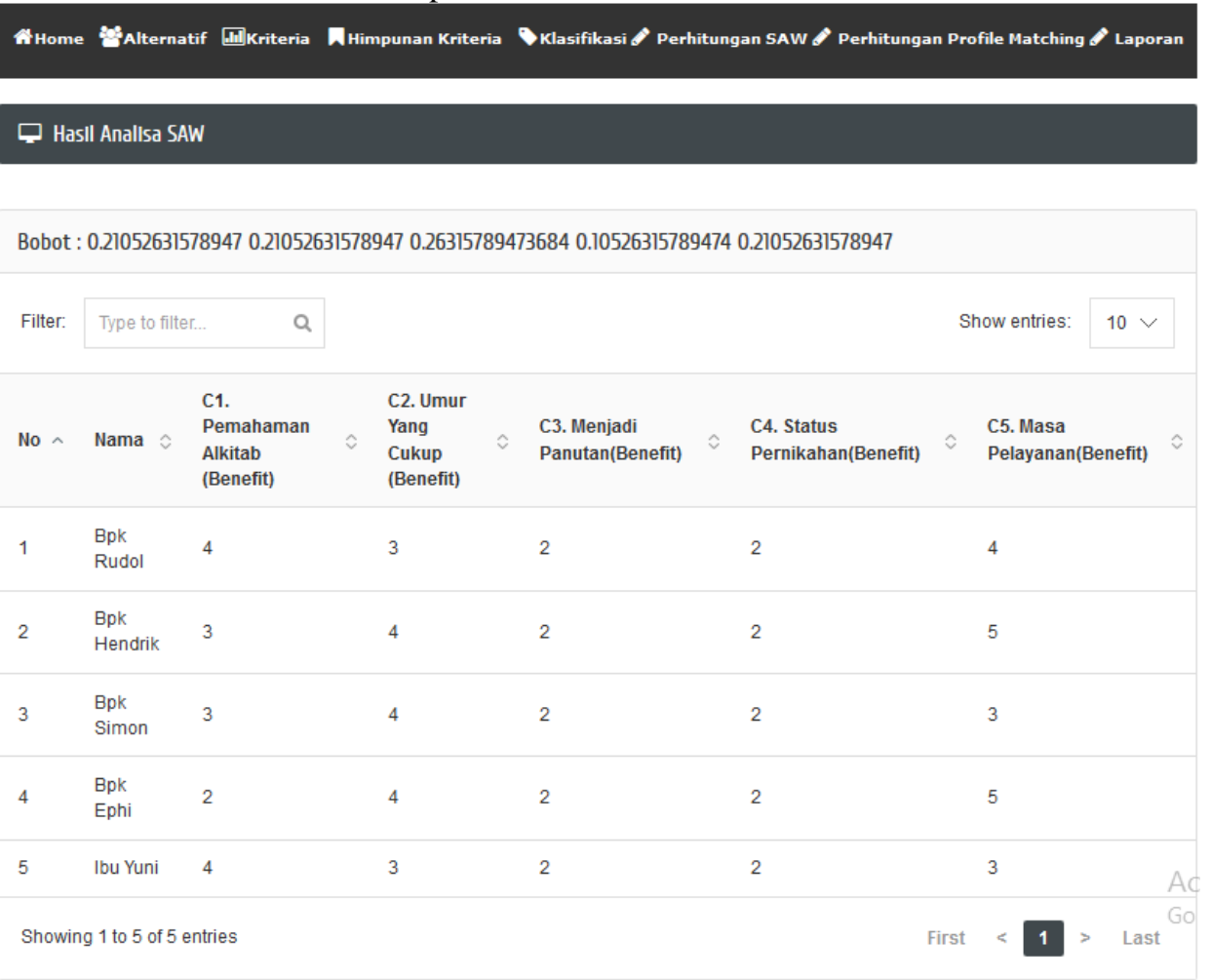

Fig 2. SAW Method Results

\section{DISCUSSION}

\section{Relative Standard Deviation (RSD) Test Value}

The following is an assessment using the SAW method and its ranking results with RSD testing:

Table 14. SAW Method

\begin{tabular}{|c|c|}
\hline Alternative & Total Value \\
\hline A1 & 0.913888889 \\
\hline A2 & 0.944444444 \\
\hline A3 & 0.855555556 \\
\hline A4 & 0.888888889 \\
\hline A5 & 0.869444444 \\
\hline \multicolumn{2}{|c|}{$\begin{array}{l}R S D=\frac{S D}{X} \times 100 \% \\
\frac{3518644}{4444444} \times 100 \%=4 \%\end{array}$} \\
\hline
\end{tabular}

The following is an assessment using the Profile Matching method and its ranking results with RSD testing:

Table 15. PM Method

\begin{tabular}{|l|l|}
\hline Alternative & Total Value \\
\hline A1 & 4.55 \\
\hline A2 & 4.15 \\
\hline A3 & 4.05 \\
\hline A4 & 4 \\
\hline A5 & 4.35 \\
\hline
\end{tabular}




$$
\begin{gathered}
R S D=\frac{S D}{X} \times 100 \% \\
\frac{0.228035085}{4.22} \times 100 \%=5 \%
\end{gathered}
$$

So the conclusion of testing using RSD, the largest percentage value is in the calculation of the Profile Matching Method with a value of 5\%, while using the SAW Method calculation obtained a value of $4 \%$.

\section{CONCLUSIONS}

Based on the results of research and analysis of the existing system in the Church of the Diaspora GKIN, the following conclusions can be drawn:

1. This decision support system can be able to display the ranking of prospective assemblies as consideration for the pastor to determine the decision making process.

2. This system uses two methods namely Simple Additive Weighting and Profile Matching to get the value of ranking results by using the RSD (Relative Standard Deviation) test to produce the largest percentage of 5\% using the Profile Matching Method.

3. This system can produce reports or final grades to be given to the pastor as a stakeholder who will determine the candidate for the assembly.

\section{REFERENCES}

[1] J. Maxwell, Artikel Inspirasi, 2012.

[2] A. Ismail, Selamat Melayani Tuhan, Jakarta: BPK Gunung Mulia, 2012.

[3] G. Barna, Menumbuhkan Murid-Murid Sejati, Jakarta: Metanoia Publishing, 2010.

[4] D. Nofriansyah, Konsep Data Mining VS Sistem Pendukung Keputusan, Yogyakarta: Deepublish, 2014.

[5] W. Supriyanti, "Rancang Bangun Aplikasi Sistem Pendukung Keputusan Penerima Beasiswa dengan Metode SAW," Citec Journal, vol. Vol.1 No.1, November 2013-Januari 20142014.

[6] A. A. T. Susilo, "Penerapan Metode Profile Matching pada Sistem Pendukung Keputusan Pemilihan Ketua Program Studi (STUDI Kasus: Program Studi Teknik Informatika STMIK Musi Rawas)," JUITA, p. 88, 2017

[7] Riki, R., \& Giap, Y. C. Design of Acceptance Decision Support System for New Employees in the Technician Position Using AHP and TOPSIS Methods at CV. Techindo Global Solution. bit-Tech, 1(2), 2129, 2018. 